\author{
Ahlam Otaibi Alghanmi, \\ King Abdulaziz University Hospital, Saudi Arabia \\ (iD) ORCID ID 0000-0002-5846-5121 \\ email: aoalghanmi@kau.edu.sa
}

\title{
INNOVATIONS AS THE COMPETITIVE ADVANTAGE FOR SMALL AND MEDIUM ENTERPRISES: THE CASE FOR KINGDOM OF SAUDI ARABIA
}

Abstract. There is a lack of studies on innovations and competitiveness in Small \& Medium Enterprises (SMEs) in Saudi Arabia; to fell this gap, this paper will study change as the competitive advantage for Small and Medium Enterprises: the case for Kingdom of Saudi Arabia. The study aims to explore different practices of SMEs in the Kingdom of Saudi Arabia to examine the impact of innovation strategies (Organizational, Product, Process, and Market) on the competitive advantage of SMEs. The study was conducted on one hundred and forty-seven (147) SMEs that are practising different activities in the Kingdom of Saudi Arabia. The study's analysis indicates that most of the enterprises were young (operation years were less than ten years), which shows the strong need to apply innovative strategies to maintain their position and competitiveness in the market. Competitive advantage enables the firm to utilise its resources efficiently and maintain high levels of quality performance. The results show that the correlation between Innovation strategies such as product innovation strategy, market innovation strategy, process innovation strategy, and organisational innovation strategy practised by SMEs in the Kingdom of Saudi Arabia and competitiveness was Positive. Therefore, it indicates that different innovation strategies were significantly influencing the competitiveness of the SMEs. To remain a competitor enterprise in the market is not a natural or an easy attempt, and it can be challenging for SMEs, especially without the needed knowledge and support. Findings and recommendations of the study can be used as a guideline for SMEs. Also, emphasising on the importance of education that plays a vital role in SMEs innovations. It is essential to establish with different research centres and universities in the Kingdom of Saudi Arabia programs or activities that focus on changes in business, and it will result in gaining competitive advantage and sustainability for Small and Medium Enterprises in the Market.

Keywords: competitive advantage, innovation, small enterprises, medium enterprises.

Introduction. The world of business is characterised by high instability and continuously changing. The common challenges in the world of business requirements for small and medium enterprises are required to be prepared to support innovation and establish a competitive advantage in the market. A competitive advantage benefits an organisation by making it stand out against competitors in one or more ways, which include, and are not limited to, introducing new products or services. Becoming competitive in the market is not an easy endeavour; it requires paying attention to the importance of innovation in all organisational processes and activities. Competitive advantage is one of the essential topics for continuity. This importance lies in that it enables a business firm to exhibit superior performance in one aspect or more in a manner that is considered superior to that of other competitors. Attaining competitive advantage requires a firm to focus on some strategies and improving the firm's public image (Epetimehin, 2011). Despite the importance of fostering innovation in business operations to attain competitive advantage, a large proportion of business firms fail to make innovation a reality in their work due to it being costly (Brunow and Miersch, 2015). Furthermore, these restrictions make attaining a competitive advantage in the market challenges, especially that modern markets are rife with competitors and fast-paced changes in various factors, and this point is needed to be regarded as one of the systematic considerations (Mburu, 2016).

Competitive advantage and Innovation Strategies: according to Professor Porter the leading authority on competitive strategy and international competitiveness, competitive advantage is seen because the

Cite as: Alghanmi, A. O. (2020). Innovations as the Competitive Advantage for Small and Medium Enterprises: the Case for the Kingdom of Saudi Arabia. Marketing and Management of Innovations, 2, 196-205. http://doi.org/10.21272/mmi.2020.2-14 

of Saudi Arabia

ability that is gained from attributes and resources and permits the firm to perform at a more substantial level than others within the same trade. He suggested that call should be created by a firm whether to try to achieve a competitive advantage by lowering the price of production than for its competitors or differentiation and sell them at a premium price. Porter Generic Competitive Advantage Strategies: The competitive advantage Professor Porter, «Cost Leadership named generic strategies», «Differentiation» (by producing unique, wanted products and services) and «Focus» (by offering exceptional service in a niche market), the Focus strategy divided into: «Cost Focus» and «Differentiation Focus», which is shown in Figure 1.

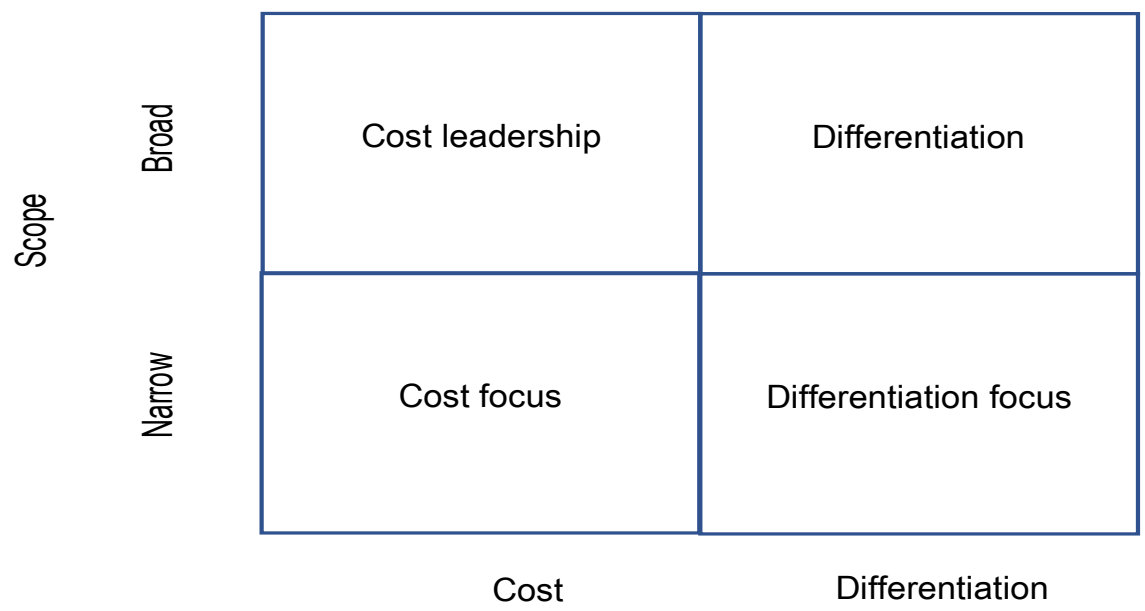

Figure 1. Porter generic Competitive Advantage Strategies (Mind Tools Porter's Generic

Source: Mind Tools Content Team, (n. d.). Strategies)

Innovation has become an essential need in the world of business; intense competition in today's markets can be a reason for increasing the global environment of a company, besides continually developing and evolving technologies (Kalkan et al., 2014). The main types of innovation in new market are:

1. Innovation related to administration and technical aspects;

2. Innovation in processes and products;

3. Incremental and radical Innovation (Liao and Wu, 2010).

Innovation Strategies: can be divided into four strategies: product/service innovation, process innovation, market innovation, and organisational Innovation (Adriopoulos and Dawson, 2009).

In the Kingdom of Saudi Arabia, there is attention for supporting Small and Medium-sized Enterprises (SMEs) to be an essential contributor to the development and growth of the economy. The General Authority provides this support for Small and Medium Enterprises; it called in Arabic «Monshaat» one of their goals is to increase SME's participation in GDP by $20 \%$ of GDP to $35 \%$ by 2030 . The diagram below shows the primary services provided to SMEs by «Monshaat», which are considered the main pillars of services presented. The technical definition of SME may differ from country to country. According to the General Authority for Small and Medium Enterprises «Monshaat» SMEs are divided into three groups:

- Micro 1-5 employees.

- Small 6-10 employees.

- Medium 11-250 employees. 


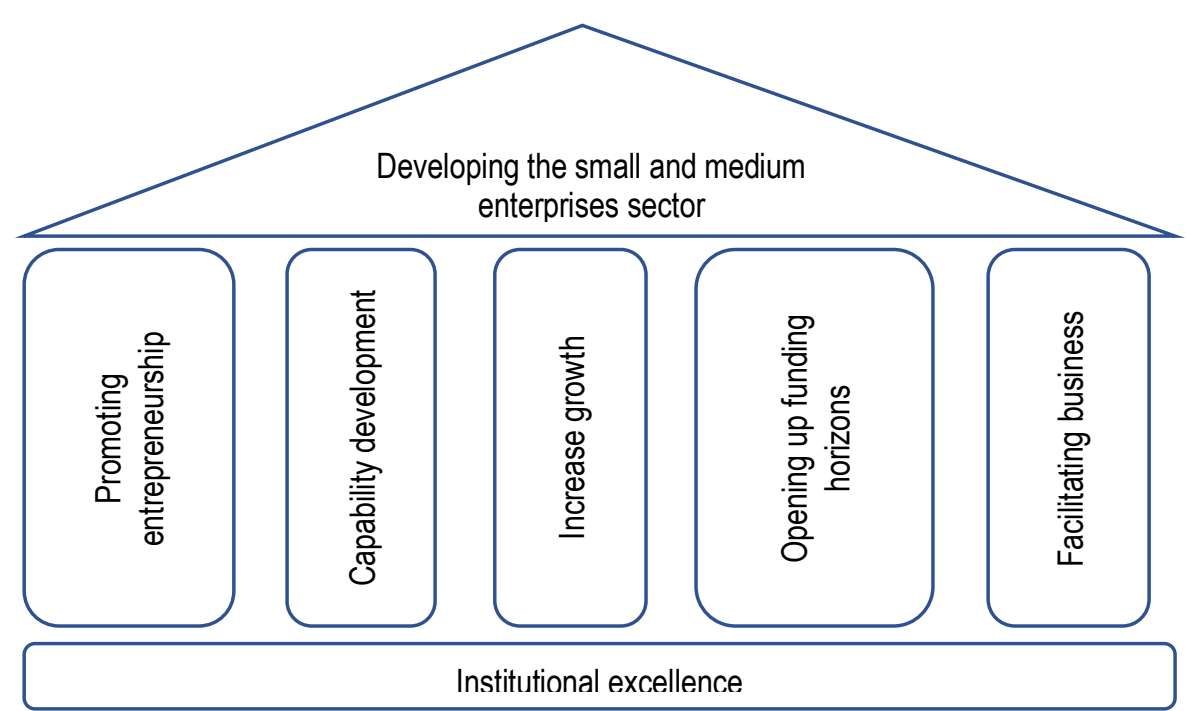

Source: Monshaat (2019).

Figure 2. SMEs Support Pillars

Innovation is an essential catalyst for success in the modern world of business and a new subject in the Gulf countries. High levels of change lead to improved organisational learning. Innovation involves the introduction and successful implementation of new ideas to make improvements in the organisation. Simulating innovation within the organisation is an essential part of the main requirements for attaining competitive advantage (Hussain and llyas, 2011). The role of innovation in attaining competitive advantage has long been discussed in other countries. Innovation is associated with an improved competitive advantage due to being related to various positive outcomes, such as increased ability to meet customers' expectations, increased technological improvements, and building forecasts on customers' behaviours (Chahal and Bakshi, 2014). Furthermore, despite that innovation results in positive organisational outcomes, it is challenging for small and medium enterprises to turn these impacts into an improved competitive advantage, especially in the light of high competitiveness in today's markets (Wingwon, 2012). Managers of SMEs often lack the necessary skills for managing change with accordance to the needs of attaining competitive advantage, in such an environment competitive position could be challenging for SMEs (Urbancova, 2013). The problem of the study can be demonstrated through the following central question: What is the role of innovation in building competitive advantage for SMEs in the Kingdom of Saudi Arabia? Especially after the Saudi vision for 2030.

Literature Review. It has been observed and believed that innovation and competitive advantage are directly or indirectly linked with the success of the business, here are the previous studies that talked about innovation and its relation to the competitive advantage of a business.

Atherton and Hannon Study (2019) highlighted on being innovative in business, they suggest for responding to small business problems that can be faced by business or customers is to have creative responses to it, which is one of the vital stages in the innovation process framework. Distanont and Khongmalai (2018) conducted a study about the innovation factors that result in creating a competitive advantage. The study was conducted on 279 SMEs in the industry of frozen food in Thailand; the finding of the study was that with innovation is essential to empower the business and create a competitive advantage that leads to sustainable economic development.

In Kuncoro and Suriani (2017) paper, they studied the relationship between product innovation and market driving and the relationship between market driving and sustainable competitive advantage. A questionnaire total of 110 people was distributed. The findings showed that the effect of Product innovation on the sustainability 
of competitive advantage is positively significant. The impact of Product innovation on Market Driving is undoubtedly substantial, and the impact of market driving on sustainable competitive advantage is positive significant, concluding that product innovation, market driving are significantly affecting the sustainability of competitive advantage. Another study was conducted by Hervas-Oliver et al. (2016) on 4,208 SMEs in Spain about process innovation. The finding of the study was that with process innovators there are two innovation patterns along, one characterised primarily by the achievement of in-person knowledge and external support from suppliers, and a second centred on the development of R\&D accompanied by organisational innovation. lonescu and Dumitru (2015) conducted a study in Romania about the role of innovation to create a company's competitive advantage. They believed that the quality of the business environment is strongly correlated to their tendency towards innovation. Urbancova (2013) conducted a paper about achieving a Competitive Advantage through Innovation and Knowledge. The study was conducted in the Czech Republic, the conclusion innovation and knowledge are vital to the competitive advantage in an organisation regardless of their size. Kraja and Osmani (2013) they emphasise on attaining competitive advantage is an essential objective for all organisations, as it has become a requirement for success because it helps to stand out against market competitors. Adhikari (2011) study was about using and exploiting new ideas, which plays a role in producing new products and improving the services in the market. Moreover, he emphasised the relationship between innovation and competitive advantage as one of the core elements in strategic management. The study was concluded with the necessity for a business to establish a culture of innovation.

Methodology and research methods. In this section, we illustrate the research methodology sampling technique and sample size, data collection procedure, and data analysis method. The present study will use the descriptive analysis which is one of the forms of structured scientific analysis to describe a specific phenomenon, by collecting data, categorise, analyse, and subject it to thorough study; since it is suitable for the nature of the present study. The sample size of the study was one hundred forty-seven (147) Enterprises in the Kingdom of Saudi Arabia. This sample size was adequate to address the research problem. According to Mugenda and Mugenda (2003) indicates that a population sample of more than 30 is an acceptable sample for studies. Information collected from respondents on innovation strategies that have been used in their enterprises and competitiveness. Primary data was collected using a closed-ended questionnaire. Closed-ended questionnaires were chosen because they can are well structured, more accessible, and quicker for respondents to answer in addressing the research question. They are also more convenient to code and statistically analyse. To avoid error editing and coding of the questionnaires was done electronically by Survey Monkey site, it is specialised for electronic surveys. The poll was conducted in Arabic to be more convenient for the respondents.

The study used the Five Likert scale. The questionnaire divided into two sections. The first section was about the profile of enterprise owners such as age, education of the owner, and the enterprise, such as the enterprise size according to the number of employees in the enterprise, years of operation. The second one focused on capturing various innovation strategies in the enterprise and its competitiveness in the Market (Boubaa, 2011).

Data analysis methodology: analysis done using SPSS program and Excel in Microsoft, data was analysed in Descriptive Statistics (Mean, Standard Deviation). Pearson correlation analysis used for the checking of relationships between Innovation strategies and Competitive Advantage of SMEs.

Result. The results will be divided into two sections. The first part was about the information of the owner and the enterprise, age, gender, education level, enterprise activity, size. The second section was about the Mean and Standard Deviation for the Innovation Strategies (Product, Process, and Organization), Competitive Advantage, then organising them Ascending according to their Means.

Table 1 shows that $55.78 \%$ of the respondent's age was under 40 years old. One hundred forty-seven (147) respondent's enterprise owners answered the electronic survey, $59.18 \%$ were Male, and $40.82 \%$ were Female. For the Female respondents, $70 \%$ of them fall within the range $21-40$, while the Male $45.98 \%$ of them within the range from $21-40$ years and $54.02 \%$ were above 40 . Thus, tell us that most of the Female owners were under forty and younger than the Male. 
A. O., Alghanmi. Innovations as the Competitive Advantage for Small and Medium Enterprises: the Case for the Kingdom of Saudi Arabia

Table 1. Age percentage

\begin{tabular}{cccc}
\hline Age Range & Percentage & Age Range & Percentage \\
\hline Less than 20 & $0 \%$ & $\mathbf{4 1 - 5 0}$ & $26.53 \%$ \\
$\mathbf{2 0 - 3 1}$ & $21.09 \%$ & More than $\mathbf{5 1}$ & $17.69 \%$ \\
$\mathbf{3 1 - 4 0}$ & $34.69 \%$ & & \\
\hline
\end{tabular}

Source: developed by the author.

Table 2 shows the level of education among the respondents, $60.54 \%$ were University graduates and $32.65 \%$ were Master and Doctorate degrees, which means most of the enterprises' owners were high level in education.

Table 2. Level of education

\begin{tabular}{cc}
\hline Education Level & Percentage \\
\hline Under Graduate & $6.80 \%$ \\
Graduate & $60.54 \%$ \\
Post Graduate & $32.65 \%$ \\
\hline
\end{tabular}

Source: developed by the author.

Table 3 with findings of 145 respond out of 147 answered this question, showing that the highest activity among the surveyed enterprises were Food services.

Table 3. Top Percentages of enterprises activity

\begin{tabular}{cccc}
\hline Enterprises Activity & Percentage & Enterprises Activity & Percentage \\
\hline Food Services & $11 \%$ & Training & $3 \%$ \\
Health sector & $10 \%$ & Consultation & $3 \%$ \\
Education services & $9 \%$ & Electrical instrument & $3 \%$ \\
Technology & $6 \%$ & Insurances & $3 \%$ \\
Construction & $6 \%$ & Technology & $3 \%$ \\
Car Services & $5 \%$ & Information Technology & $2 \%$ \\
Restaurant & $4 \%$ & &
\end{tabular}

Note: Percentage More than $1 \%$

Source: developed by the author.

Table 4 shows the size of the Enterprises that were surveyed according to the number of staff,174 respondents were classified as $78.91 \%$ Small and Medium Enterprises, and $21.09 \%$ were large Enterprises. They have ranked in size again according to the ownership (Female and Male).

Table 4. Organisation size (according to the number of staff in the enterprise) size of the enterprise

\begin{tabular}{lc}
\hline Number of Staff in the organisation & Percentage \\
\hline $\mathbf{1 - 5 0}$ (Small) & $71.43 \%$ \\
$\mathbf{5 1 - 2 5 0}$ (Medium) & $7.48 \%$ \\
More than $\mathbf{2 5 0}$ (Large) & $21.09 \%$ \\
\hline
\end{tabular}

Source: developed by the author.

The findings in Table 5 show that more than sixty per cent (66.67\%) were Small enterprises for the female respondents, and $6.67 \%$ were Medium-Sized enterprises. 
A. O., Alghanmi. Innovations as the Competitive Advantage for Small and Medium Enterprises: the Case for the Kingdom of Saudi Arabia

Table 5. Size of enterprises for the Female

\begin{tabular}{lc}
\hline Number of Staff in the organisation & Percentage \\
\hline $\mathbf{1 - 5 0}$ (Small) & $66.67 \%$ \\
$\mathbf{5 1 - 2 5 0}$ (Medium) & $6.67 \%$ \\
More than 250 (Large) & $26.67 \%$ \\
\hline
\end{tabular}

Source: developed by the author.

Table 6 shows more than seventy per cent $(74.71 \%)$ were classified as small-sized enterprises, and $8.05 \%$ were Medium-Sized enterprises. Small enterprises were higher in percentage in both Male and Female respondents.

Table 6. Size of enterprises for the Male

\begin{tabular}{lc}
\hline Number of Staff in the organisation & Percentage \\
\hline $\mathbf{1 - 5 0}$ (Small) & $74.71 \%$ \\
$\mathbf{5 1 - 2 5 0}$ (Medium) & $8.05 \%$ \\
More than 250 (Large) & $17.24 \%$ \\
\hline
\end{tabular}

Source: developed by the author.

Operational years of the enterprise: from Table 7 it shows the Operational years of enterprises that were surveyed in the study. This data was essential to understand the stability of the enterprises. More than fifty-nine per cent $(59.86) \%$ were less than ten years in operation; the utmost of the enterprises were young less than ten years.

Table 7. Operational years by percentage

\begin{tabular}{cccc}
\hline Number of Years & Percentage & Number of Years & Percentage \\
\hline Less than 10 years & $59.86 \%$ & $16-20$ years & $9.52 \%$ \\
$11-15$ years & $6.80 \%$ & More than 20 years & $23.81 \%$ \\
\hline
\end{tabular}

Source: developed by the author.

Table 8 showing the statistics data Mean and standard deviation (SD) of innovation strategies. It has been found that all data their means were more than 3 , which indicates that there is an agreement about the statement rating between the 147 respondents. From the top five by the result of the means, statement (10) in Product Innovation of the way (4.2) populates the top of other statements with its standard deviation (SD) of (0.776), which indicates that most of the surveyed enterprises agree on a report. After that, it comes statement (11.) where the mean is (4.19), and here the standard deviation is $(0.752)$ followed by the report $(5$.) of the mean (4.17) with the standard deviation of (0.847). Then the mean is (4.16) in the statement (12.) with a standard deviation of (0.875). Finally, in the fifth one of the top five is the statement (1.) of a mean of (4.1) and a standard deviation of (0.909). Generally, at all of Innovation Strategies, Product Innovation is at the top, and Market Innovation is the lowest in sequence. This point needs to be taken into consideration for the SMEs.

Table 8. Innovation strategies

\begin{tabular}{lcccc}
\hline$\#$ & Statements & Mean & SD & Sequence by Mean \\
\hline $\mathbf{1}$ & $\mathbf{2}$ & $\mathbf{3}$ & $\mathbf{4}$ & $\mathbf{5}$ \\
\hline \multicolumn{5}{c}{ Organisation Innovation } \\
\hline 1. The organisation facilitate teamwork by renewing the organisation \\
$\begin{array}{c}\text { structure } \\
\text { 2. The organisation accomplish firm activities innovatively by renewing the } \\
\text { routines, procedures and processes }\end{array}$ & 4.1 & 0.909 & $(5)$ \\
\hline
\end{tabular}


A. O., Alghanmi. Innovations as the Competitive Advantage for Small and Medium Enterprises: the Case for the Kingdom of Saudi Arabia

\begin{tabular}{|c|c|c|c|c|}
\hline \multicolumn{5}{|c|}{ Continued Table 8} \\
\hline 1 & 2 & 3 & 4 & 5 \\
\hline 3. & Renewing the human resources management system & 3.74 & 0.987 & $(16)$ \\
\hline 4. & Renewing the supply chain management system & 3.59 & 1.019 & (20) \\
\hline 5. & $\begin{array}{l}\text { Modifying the way in which its services are performed based on the } \\
\text { unsatisfied needs of customers }\end{array}$ & 4.03 & 0.831 & (7) \\
\hline 6. & $\begin{array}{l}\text { The organisation follows up customer complaints and opinions to } \\
\text { develop its services }\end{array}$ & 4.17 & 0.847 & (3) \\
\hline 7. & $\begin{array}{l}\text { The organisation provided additional services that are unique and } \\
\text { innovative compared to the competitors }\end{array}$ & 4.03 & 0.917 & (8) \\
\hline \multicolumn{5}{|c|}{ Product Innovation } \\
\hline 8. & The organisation offers a wide range of services & 3.84 & 1.032 & (12) \\
\hline 9. & The organisation has a shorter duration of obtaining a product/service & 3.64 & 1.005 & (18) \\
\hline 10. & The products/services are of satisfactory quality & 4.2 & 0.776 & (1) \\
\hline 11. & The organisation offers market-driven products and services & 4.19 & 0.752 & (2) \\
\hline 12. & Determine the needs of the expected customers & 4.16 & 0.785 & (4) \\
\hline \multicolumn{5}{|c|}{ Market Innovation } \\
\hline 13. & Renewing product promotion techniques for the products & 3.86 & 0.993 & (11) \\
\hline 14. & $\begin{array}{l}\text { Renewing the distribution channels and keeping the logistics processes } \\
\text { related to the product delivery }\end{array}$ & 3.67 & 0.861 & $(17)$ \\
\hline 15. & Renewing the techniques of product pricing for products & 3.81 & 0.946 & (13) \\
\hline 16. & Renewing activities of the general market management & 3.79 & 0.923 & (14) \\
\hline \multicolumn{5}{|c|}{ Process Innovation } \\
\hline 17. & $\begin{array}{c}\text { Determine and eliminate the activities with non-added value in the } \\
\text { delivery process }\end{array}$ & 3.93 & 0.865 & (9) \\
\hline 18. & $\begin{array}{l}\text { Decrease variable cost and/or increasing delivery speed in delivery } \\
\text { processes }\end{array}$ & 4.06 & 0.838 & (6) \\
\hline 19. & The organisation has introduced new machinery and equipment & 3.63 & 1.105 & (19) \\
\hline 20. & The organisation has made changes in the production process & 3.56 & 1.021 & (21) \\
\hline
\end{tabular}

Source: developed by the author.

Table 9 showing competitive advantage strategies. The top five by the result of their means. Thus, it has been found that all data their ways were more than 3 , which indicates that there is an agreement about the statement rating between the 147 respondents. In the statement (4), the mean (3.97) populates the top of other statements with its standard deviation of $(0.965)$, which means that most of the respondent.

Then comes the statement (1) where the mean is (3.95), and here the standard deviation is $(0.95)$ followed by the report (5) of the third mean (3.95) with the standard deviation of (0.995). Next, is the fourth statement with the mean of (3.95) in the report (6) with a standard deviation of (0.917). Finally, in the fifth one of the top five is the statement (3) of a mean of (3.88) and a standard deviation of $(0.910)$.

Table 9. Competitive advantage

\begin{tabular}{|c|c|c|c|c|}
\hline \# & Statement & Mean & SD & Sequence by Mean \\
\hline 1 & 2 & 3 & 4 & 5 \\
\hline \multicolumn{5}{|c|}{ Cost Leadership } \\
\hline & The organisation seeks to maintain efficient elements to reduce costs & 3.95 & 0.953 & (2) \\
\hline & $\begin{array}{l}\text { The organisation benefits from economies of scale when getting the raw } \\
\text { materials of the enterprise }\end{array}$ & 3.75 & 0.875 & (8) \\
\hline & $\begin{array}{l}\text { The organisation seeks to produce its products/services at the lowest cost } \\
\text { to control its market share }\end{array}$ & 3.88 & 0.91 & (5) \\
\hline
\end{tabular}


A. O., Alghanmi. Innovations as the Competitive Advantage for Small and Medium Enterprises: the Case for the Kingdom of Saudi Arabia

\begin{tabular}{|c|c|c|c|c|}
\hline & & & & Continued Table 9 \\
\hline 1 & 2 & 3 & 4 & 5 \\
\hline \multicolumn{5}{|c|}{ Differentiation } \\
\hline & $\begin{array}{l}\text { The organisation is distinguished by the experience and skills than the } \\
\text { competitors }\end{array}$ & 3.97 & 0.965 & (1) \\
\hline 5. & $\begin{array}{l}\text { The organisation keen to attract individuals with academic qualifications } \\
\text { and practical competence }\end{array}$ & 3.95 & 0.995 & (3) \\
\hline 6. & $\begin{array}{l}\text { The organisation is distinguished by its excellent services/products from } \\
\text { the rest of the competitors }\end{array}$ & 3.95 & 0.917 & (4) \\
\hline \multicolumn{5}{|c|}{ Flexibility } \\
\hline & $\begin{array}{l}\text { The organisation has high flexibility in controlling the volume of production } \\
\text { of its products/services to that suit the fluctuations demand in the Market }\end{array}$ & 3.78 & 0.949 & (7) \\
\hline & $\begin{array}{c}\text { The organisation has high flexibility in responding to changes in the } \\
\text { customer's needs }\end{array}$ & 3.87 & 0.931 & (6) \\
\hline & $\begin{array}{l}\text { The high flexibility in production processes distinguishes the organisation } \\
\text { in terms of flexibility in machines and equipment }\end{array}$ & 3.65 & 0.905 & (9) \\
\hline
\end{tabular}

Source: developed by the author.

The following tables represent the correlation in this study, which described by the questionnaire data between Innovation Strategies and Competitive Advantage using the SPSS program. Table 10 shows that there is an existed positive relationship $(r=0.425)$ between Organization Innovation and Cost Leadership Competitive advantage, Organization Innovation and Differentiation Competitive Advantage ( $r=.485)$, Organization Innovation with Flexibility Competitive advantage ( $r=4.99)$.

Table 10. Organisation Innovation with Competitive advantage strategies

\begin{tabular}{cccc}
\hline Competitive Advantage & Cost Leadership & Differentiation & Flexibility \\
\hline Organisation Innovation & $0.425^{\star *}$ & $0.485^{* *}$ & $0.499^{* *}$ \\
N & 147 & 147 & 147 \\
\hline
\end{tabular}

${ }^{* *}$ At the 0.01 level (2-tailed) Correlation is significant.

Source: developed by the author.

Also, in Table 11, it is showing that there is a significant correlation between product-service Innovation and Competitive advantage.

Table 11. Product Innovation with Competitive advantage strategies

\begin{tabular}{cccc}
\hline Competitive Advantage & Cost Leadership & Differentiation & Flexibility \\
\hline Product Innovation & $0.533^{* *}$ & $0.625^{\star *}$ & $0.549^{\star *}$ \\
N & 147 & 147 & 147 \\
\hline
\end{tabular}

${ }^{* *}$ At the 0.01 level (2-tailed) Correlation is significant.

Source: developed by the author.

Table 12 in the Market innovation showing again that there is a significant correlation between productservice Innovation and Competitive advantage.

Table 12. Market Innovation with Competitive advantage strategies

\begin{tabular}{cccc}
\hline Competitive Advantage & Cost Leadership & Differentiation & Flexibility \\
\hline Market Innovation & $0.543^{* *}$ & $0.600^{\star *}$ & $0.619^{* *}$ \\
N & 147 & 147 & 147 \\
\hline
\end{tabular}

${ }^{* *}$ At the 0.01 level (2-tailed) Correlation is significant.

Source: developed by the author. 
A. O., Alghanmi. Innovations as the Competitive Advantage for Small and Medium Enterprises: the Case for the Kingdom of Saudi Arabia

In Table 13, the process innovation, it is showing that there is a significant correlation between process Innovation and Competitive advantage.

Table 13. Process Innovation with Competitive advantage strategies

\begin{tabular}{cccc}
\hline Competitive Advantage & Cost Leadership & Differentiation & Flexibility \\
\hline Process Innovation & $0.545^{* *}$ & $0.513^{* *}$ & $0.609^{\star *}$ \\
N & 147 & 147 & 147 \\
\hline
\end{tabular}

${ }^{* *}$ At the 0.01 level (2-tailed) Correlation is significant.

Source: developed by the author.

The results indicated that Innovation strategies such as product innovation strategy, market innovation strategy, process innovation strategy, and organisational innovation strategy practised by SMEs in the Kingdom of Saudi Arabia showed that the contributing relationship between innovation and competition was Positive. Therefore, it indicates that innovation strategies were significantly influencing competitiveness.

Conclusion. The analysis indicates that most of the enterprises were young (less than ten years), which there is a strong necessitate to apply innovative strategies to maintain their position and competitiveness in the market. Competitive advantage enables the firm to utilise its resources efficiently and maintain high levels of performance quality in the market. Becoming competitive in the market is not a natural attempt and can be challenging for some SMEs, especially without the support and knowledge (Urbancova, 2013). Innovation is not creativity and not an invention; these terms are open to misinterpretation Atherton and Hannon (2019). Some think of it as a broad-ranging creative process, others only as ideas generation. All enterprises that were surveyed showed that innovation strategies were significantly influencing competitive advantage. Moreover, there is a significant correlation between Innovation strategies and Competitive advantage, which answer the question about the role of innovation in building competitive advantage in SMEs. The concept of innovation among enterprises needs more focus, adding to it the knowledge by specialised organisations such as (Monshaat) or Entrepreneurship centres in the Universities (Kamasak \& Bulutlar, 2010). SMEs may have to put innovation as a strategic priority to create a competitive advantage (Wingwon, B. 2012), also modifying their business models to adapt to the changing environment especially with the Saudi Vision 2030. SMEs can come more internationalised, upgrade the quality of their human capital, adopt more IT solutions, and improve their corporate governance (Dubai SME, 2013). There is a big opportunity for Saudi researchers in the field of (Innovation and Competitive Advantage in SMEs) to do more studies and have networks with research centres nationally and Internationally. Universities, entrepreneurship centres can cooperate and give support by facilitating these researches, which will ultimately result to gain sustainability and competitiveness for the business in the market. Like other studies, this study is based on competitive advantage, product innovation, market innovation, process innovation, and organisation innovation data for the respective 147 enterprises and thus interpretations deviating from the findings of this study may occur if the period is outside the study period or if the variables are not the same.

\section{References}

Adhikari, M. B. (2011). Innovation: Tools to Create Competitive Advantage for Business. Available at SSRN 1874666. [Google Scholar]

Atherton, A. \& Hannon, P. (2019). The innovation process in the small business: an analysis of its structure, dynamics and constituent parts. In ICSB Global Conference. [Google Scholar]

Boubaa, A. W. (2011). Role of the Professor Edrem the official electoral messages field, the system administrations, the pigeonhole resonances of the human being, scheduled - Enbilis - Unpublished Master Thesis, University of Mentouri - Algeria.

Brunow, S., \& Miersch, V. (2015). Innovation capacity, workforce diversity and intra-industrial externalities: a study of German establishments. In The Rise of the City. Edward Elgar Publishing. [Google Scholar] [CrossRef]

Chahal, H., \& Bakshi, P. (2014). Effect of intellectual capital on competitive advantage and business performance: role of innovation and learning culture. Intemational Journal of Learning and Intellectual Capital, 11(1), 52-70. [Google Scholar] [CrossRef] 
A. O., Alghanmi. Innovations as the Competitive Advantage for Small and Medium Enterprises: the Case for the Kingdom of Saudi Arabia

Distanont, A., \& Khongmalai, O. (2018). The role of innovation in creating a competitive advantage. Kasetsart Journal of Social Sciences. [Google Scholar] [CrossRef]

Dubai SME. (2013). The state of Small \& Medium enterprises (SMES) in Dubai. Retrieved from http://www.sme.ae/studiesandresearchdocument/sme report english.pdf

Epetimehin, F. M. (2011). Achieving competitive advantage in insurance industry: The impact of marketing innovation and creativity. Journal of emerging trends in economics and management sciences, 2(1), 18-21. [Google Scholar]

Hervas-Oliver, J. L., Boronat-Moll, C., \& Sempere-Ripoll, F. (2016). On Process Innovation Capabilities in SMEs: A Taxonomy of Process-Oriented Innovative SMEs. Small Business Management, 54(S1), 113-134. [Google Scholar] [CrossRef]

Hussain, M. F., \& llyas, S. (2011). Environment for Innovation: Gaining competitive advantage. African Journal of Business Management, 5(4), 1232-1235. [Google Scholar]

Ionescu A. \& Dumitru, N. R. (2015). The Role of Innovation in Creating the Company's Competitive Advantage. Ecoforum Journal, 4(1), 14. [Google Scholar]

Kalkan, A., Bozkurt, O. C., \& Arman, M. (2014). The impacts of intellectual capital, innovation and organisational strategy on firm performance. Procedia-Social and Behavioral Sciences, 150, 700-707. [Google Scholar] [CrossRef]

Kamasak, R., \& Bulutlar, F. (2010). The influence of knowledge sharing on innovation. European Business Review, 22(3), 306-317. [Google Scholar] [CrossRef]

Kraja, Y., \& Osmani, E. (2013). Competitive advantage and its impact in small and medium enterprises (SMEs)(Case of Albania). European Scientific Journal, 9(16), 76-85. [Google Scholar]

Kuncoro, W., \& Suriani, W. O. (2018). Achieving sustainable competitive advantage through product innovation and market driving. Asia Pacific Management Review, 23(3), 186-192. [Google Scholar] [CrossRef]

Liao, S. H., \& Wu, C. C. (2010). System perspective of knowledge management, organisational learning, and organisational innovation. Expert systems with Applications, 37(2), 1096-1103. [Google Scholar] [CrossRef]

Mburu, P. W. (2016). Relationship Between Innovation Strategies and Competitive Advantage in the logistics firms in Mombasa County, Kenya. Unpublished Master Thesis, University of Nairobi. Retrieved from http://erepository.uonbi.ac.ke/handle/11295/98589

Mind Tools Content Team. (n.d.). Porter's Generic Strategies: Choosing Your Route to Success. Retrieved from https://www.mindtools.com/pages/article/newSTR 82.htm

Monshaat Supporting Pillars. Retrieved from https://www. monshaat.gov.sal

Mugenda, O., \& Mugenda, A. G. (2003). Research methods: Quantitative and Qualitative methods. Revised in Nairobi.

Urbancova, H. (2013). Competitive advantage achievement through innovation and knowledge. Joumal of competitiveness, $5(1)$ [Google Scholar] [CrossRef]

Wingwon, B. (2012). Effects of Entrepreneurship, Organisation Capability, Strategic Decision Making and Innovation toward the Competitive Advantage of SMEs Enterprises. Journal of Management and Sustainability, 2(1), 137-150. [Google Scholar]

\section{Ахлам Отайбі Алганмі,}

Університетська лікарня короля Абдулазіза, Саудівська Аравія

Інновації як конкурентна перевага малих та середніх підприємств: досвід Саудівської Аравії

На основі результатів систематизації наукових джерел автором обгрунтовано наявність розриву між впровадженням інновацій та рівнем конкурентоспроможності малих і середніх підприємств. Автором висунуто гіпотезу про наявність взаємозв'язку між інноваціями та еффективністю фуункиіонування малих і середніх підприємств Саудівської Аравії. Емпіричне дослідження проведено на основі панельних даних, ссормованих для вибірки з 147 малих і середніх підприємств Саудівської Аравії, які функціонують у різних галузях економіки. Встановлено, що більшості малих і середніх підприємств Саудівської Аравії є відносно молодими та функціонують на ринку меншим ніж 10 років. У свою чергу, це обумовлює необхідність пошуку нових інструментів підвищення їх конкурентоспроможності з метою зміинення позицій на ринку. Емпіричні результати підтверджують статистичну значущість впливу інноваційних стратегій на рівень конкурентоспроможності малих середніх підприємств на внутрішньому ринку. При цьому зазначено, що конкурентні переваги сприяють раціональному використанню ресурсів підприємства, а також забезпеченню підвищенню ефективності виробничого процесу. Зазначено, що найбільший статистично значущий вплив мають такі фактори як: асортимент продукції; технологій виробництва; позииіювання на ринку; організаційна культура. Автором наголошено, що високий рівень конкуренції на ринку вимагає від малих та середніх підприємств постійного впровадження нових технологій та підвищення кваліфікації працівників. Доведено необхідність розвитку колоборації між закладами вищої освіти, центрами наукових досліджень та малими і середніми підприємствами у Саудівській Аравії, що забезпечить обмін знаннями та підвищення конкурентних переваг малих і середніх підприємствам не лише на внутрішньому, а й на світовому ринках. Результати дослідження мають практичне значення і можуть бути прийняті для впровадження менеджментом малих і середніх підприємств у якості рекомендаиій щодо підвищення рівня конкурентоспроможності.

Ключові слова: конкурентна перевага, інновація, малі підприємства, середні підприємства.

Manuscript received: 25.10.2019

(C) The author(s) 2020. This article is published with open access at Sumy State University. 